\title{
Cropping System Intensification for Increasing Crop Productivity in Salt-Affected Coastal Zones of Bangladesh $^{+}$
}

\author{
Rina Rani Saha 1,*, Md. Alimur Rahman 2, Md. Hafijur Rahman 3, Mohammed Mainuddin 4, \\ Richard Bell ${ }^{5}$ and Don S. Gaydon ${ }^{6}$ \\ 1 Bangladesh Agricultural Research Institute (BARI), Gazipur-1701, Bangladesh; saharinarani@yahoo.com \\ 2 Regional Agricultural Research Station (RARS), BARI, Barishal 8211, Bangladesh; alimurbd@yahoo.com \\ 3 Regional Agricultural Research Station (RARS), BARI, Jashore 7403, Bangladesh; \\ hafijrahman05@gmail.com \\ 4 CSIRO Land and Water, Canberra, ACT 2601, Australia; Mohammed.Mainuddin@csiro.au \\ 5 Sustainable Land Management, School of Veterinary and Life Sciences, Murdoch University, \\ Perth WA-6150, Australia; r.bell@murdoch.edu.au \\ 6 CSIRO Agriculture and Food, Brisbane, QLD 4067, Australia; Don.Gaydon@csiro.au \\ * Correspondence: saharinarani@yahoo.com \\ + Presented at the third International Tropical Agriculture Conference (TROPAG 2019), Brisbane, Australia, \\ 11-13 November 2019.
}

Published: 7 April 2020

\begin{abstract}
In Global Climate Risk Index 2019, Bangladesh has been ranked seventh among the countries most affected by extreme weather events. The salinity intrusion has increased by $27 \%$ from 1973 to 2009 in coastal areas of Bangladesh due to impacts of climate change. The cropping intensities of the coastal zones are below than the country's average intensity (195\%), which causes severe food insecurity. In southern coastal zone, soil and water (river/canal) salinity remain the minimum $(<4 \mathrm{dS} / \mathrm{m})$ during in July/August but attain the maximum (upto 11 and $25 \mathrm{dS} / \mathrm{m}$, respectively) in March/April. Farmers grow single T.aman rice a year. Therefore, five cropping patterns were tested under ACIAR funded project in Amtali (Barguna district) and Dacope (Khulna) upazilas during 2016-2017 and 2017-2018 irrigating with low salinity surface water (canal/pond) to increase crop productivity. In Amtali, T.aman-Potato-Mungbean-T.aus cropping pattern gave the highest (20.18 t/ha) rice equivalent yield (REY), which increased $360 \%$ REY over the farmers' practice (T.aman-fallow-fallow). However, in Dacope, T.aman-spinach-fallow showed the highest REY (13.99 t/ha) that increased 211\% REY compared to farmers' practice. The improved cropping patterns can be practiced within the polder (embankment for water control) for increasing crop productivity and profitability in salt-affected coastal zones of Bangladesh.
\end{abstract}

Keywords: cropping system intensification; crop productovity; salt-affected coastal zone; Bangladesh

(C) 2020 by the authors. Licensee MDPI, Basel, Switzerland. This article is an open access article distributed under the terms and conditions of the Creative Commons Attribution (CC BY) license (http://creativecommons.org/licenses/by/4.0/). 